\title{
Liopropoma incandescens sp. nov. (Epinephelidae, Liopropominae), a new species of basslet from mesophotic coral ecosystems of Pohnpei, Micronesia
}

\author{
Hudson T. Pinheiro', Bart Shepherd', Brian D. Greene², Luiz A. Rocha' \\ I California Academy of Sciences, San Francisco, CA 94118, USA 2 Association for Marine Exploration, \\ Kaneohe, HI 96744, USA \\ Corresponding author: Hudson T. Pinheiro (htpinheiro@gmail.com)
}

Academic editor: N. Bogutskaya | Received 14 February 2019 | Accepted 29 May 2019 | Published 11 July 2019

http://zoobank.org/OC03A49B-BF84-44BD-A516-77CEF3F81D2D

Citation: Pinheiro HT, Shepherd B, Greene BD, Rocha LA (2019) Liopropoma incandescens sp. nov. (Epinephelidae, Liopropominae), a new species of basslet from mesophotic coral ecosystems of Pohnpei, Micronesia. ZooKeys 863: 97-106. https://doi.org/10.3897/zookeys.863.33778

\begin{abstract}
A new species of the genus Liopropoma Gill found on the lower mesophotic coral ecosystem of Pohnpei, Micronesia, is herein described. Liopropoma incandescens sp. nov. differs from its congeners in coloration, number of lateral-line scales, number of pectoral fin rays, body depth, and snout length. Liopropoma incandescens sp. nov. is the $31^{\text {st }}$ species in the genus. It was collected from a small rocky crevice in a steep slope at $130 \mathrm{~m}$ depth. Water temperature was $20^{\circ} \mathrm{C}$ and benthic habitat was dominated by gorgonians, sponges and tunicates.
\end{abstract}

\section{Keywords}

closed-circuit rebreather, coral-reef twilight zone, reef fish, SubCAS, taxonomy

\section{Introduction}

Despite significant recent growth on research in mesophotic coral ecosystems (MCEs, 30-150 m depth), exploration at these depths is still yielding high rates of new species discovery worldwide (Rocha et al. 2017, Pinheiro et al. 2018, Pyle et al. 2018, Shepherd et al. 2018a, Arango et al. 2019). Through rebreather technical diving to depths up to $150 \mathrm{~m}$, the Hope for Reefs Initiative of the California Academy of Sciences is 
advancing the knowledge ca. the biodiversity and ecology of MCEs conducting on average four expeditions per year. MCEs shelter unique communities, and much like their shallow coral ecosystem counterparts, are being affected by overfishing, pollution and climate change (Rocha et al. 2018).

Coral reefs of the Central Pacific are home to a high fish diversity, with over 2,300 species (Kulbicki et al. 2013). Pohnpei, one of the four states in the Federated States of Micronesia, has well-developed shallow coral reefs and MCEs, which also harbor diverse mesophotic fish communities (Coleman et al. 2018, Rocha et al. 2018). Technical diving exploration in Pohnpei MCEs has yielded the recent descriptions of species in the genera Luzonichthys Herre (e.g., Copus et al. 2015) and Tosanoides Kamohara (e.g., Pyle et al. 2018). Although overall richness decreases significantly along the depth gradient, high betadiversity, driven mainly by species turnover, differentiates shallow from deep reefs in the region (Coleman et al. 2018, Rocha et al. 2018).

The serranid genus Liopropoma Gill is a typical inhabitant of MCEs, with the most recent species being described from the Caribbean (Baldwin and Robertson 2014; Baldwin and Johnson 2014). It is characterized by VIII, 11-14 dorsal fin rays, III, 8-11 anal rays, weak ctenoid scales on the body, a complete lateral line (highly arched over pectoral fin) with 44-66 pored scales, and a band of villiform teeth in both jaws lacking canines (Kon et al. 1999). According to Eschmeyer and Fong (2018), Liopropoma currently contains 30 recognized species, 22 of which are distributed in the IndoPacific region, with a further eight species in the Western and Eastern Atlantic. These authors consider Liopropoma danae (Kotthaus) as a doubtful species, almost certainly a synonym of a valid species, described based on juvenile specimens. During our latest expedition to Pohnpei in August of 2017, we discovered a new species of Liopropoma at $130 \mathrm{~m}$ depth at Ahnd (Ant) Atoll. Here we describe Liopropoma incandescens sp. nov. as the $31^{\text {st }}$ species of the genus.

\section{Materials and methods}

The specimen was collected with hand nets during a deep dive using mixed-gas, closed-circuit rebreathers, and brought to the surface alive in the SubCAS submersible fish decompression chamber (Shepherd et al. 2018b). It was placed in a $1 \mathrm{~L}$ plastic bag filled with seawater and pure oxygen in equal ratios, packed inside a Styrofoam box with a cardboard outer liner, and transported alive via air cargo to San Francisco, where it was photographed and euthanized following California Academy of Sciences institutional animal care and use committee (IACUC) guidelines. Counts were performed with a stereo microscope, and morphological characters were measured to the nearest $0.01 \mathrm{~mm}$ with digital calipers following the conventions described in Baldwin and Robertson (2014). Body proportions are expressed as percentage of standard length (SL). Comparative material included Liopropoma africanum (Smith) (CAS 32371), one specimen $37.67 \mathrm{~mm}$ SL, from Comoros Islands, collected 25-30 m depth; Liopropoma collettei Randall \& Taylor (CAS 228952), one specimen 54.55 
mm SL, from Honolulu, Hawaii, collected ca. $15 \mathrm{~m}$ depth; Liopropoma fasciatum Bussing (CAS 46579), one specimen $117.30 \mathrm{~mm}$ SL, from Galapagos, Ecuador, collected ca. $20 \mathrm{~m}$ depth; Liopropoma latifasciatum (Tanaka) (CAS 243779), one specimen $54.06 \mathrm{~mm}$ SL, from Okinawa, Japan; Liopropoma longilepis Garman (CAS 86404), one specimen $145.52 \mathrm{~mm} \mathrm{SL}$, from Galapagos, Ecuador, collected from a submersible down to 200 m; Liopropoma mitratum Lubbock \& Randall (CAS 27698), one specimen 41.06 mm SL, from Raroia Atoll, French Polynesia, collected ca. 10 m depth; Liopropoma mowbrayi Woods \& Kanazawa (CAS 56894), one specimen 43.40 mm, from U.S. Virgin Islands; and Liopropoma susumi (Jordan \& Seale) (CAS 214155), one specimen $52.01 \mathrm{~mm} \mathrm{SL}$, from the American Samoa, collected ca. $15 \mathrm{~m}$ depth; along with a revision of the genus by Randall and Taylor (1988). The holotype was deposited at the California Academy of Sciences (CAS) ichthyological collection.

\section{Results}

\section{Liopropoma incandescens sp. nov.}

http://zoobank.org/ADC07533-17B1-4FAC-9C56-67C47D8AB8AD

Figures 1, 2

Incandescent Basslet

Type locality. Ant Atoll, Pohnpei, Micronesia.

Holotype. CAS 246199, 54.15 mm SL, Federated States of Micronesia, Pohnpei, Ahnd (Ant) Atoll, west side, 6.75589N, 157.91933E, 29 August 2017, B. D. Greene, hand nets, $130 \mathrm{~m}$ depth.

Diagnosis. Liopropoma incandescens sp. nov. can be distinguished from all of its congeners by the yellow to orange body color (Figure 1A), with two distinctive black blotches on the upper and lower caudal fin lobes (Figure 1A, B), and by the following combination of characters: dorsal fin VIII,13; anal fin III, 9; pectoral fin 14; total gill rakers on first arch 15; lateral-line scales 62; length of first dorsal-fin spine 5\% SL; depth at origin of dorsal fin 22\% SL; least depth of caudal peduncle $15 \%$ SL; orbit diameter 9\% SL.

Description. Dorsal-fin rays VIII, 13 (spines not embedded into the skin, and the last two soft rays are associated with a single complex pterygiophore; Figure 1C); anal-fin rays III, 9 (last two soft rays associated with a single complex pterygiophore); pectoral-fin rays 14 , dorsal-fin-most ray unsegmented; pelvic-fin rays I, 5; principal caudal-fin rays $8+7=15$; rudimentary and procurrent caudal-fin rays $10+9=19$; pored lateral-line scales 62; scales from lateral line to dorsal fin origin 6; scales from lateral line to anal fin origin 22; gill rakers on first arch, including rudiments, $6+9$; vertebrae $8+15$ (Figure 1C).

Measurements presented as percentage of standard length (SL): body depth at origin of dorsal fin 21.8; body width just behind gill opening 14.9; head length 38; snout length 9.5; orbit diameter 8.6; bony interorbital width 6.4; upper-jaw length 14.7; 


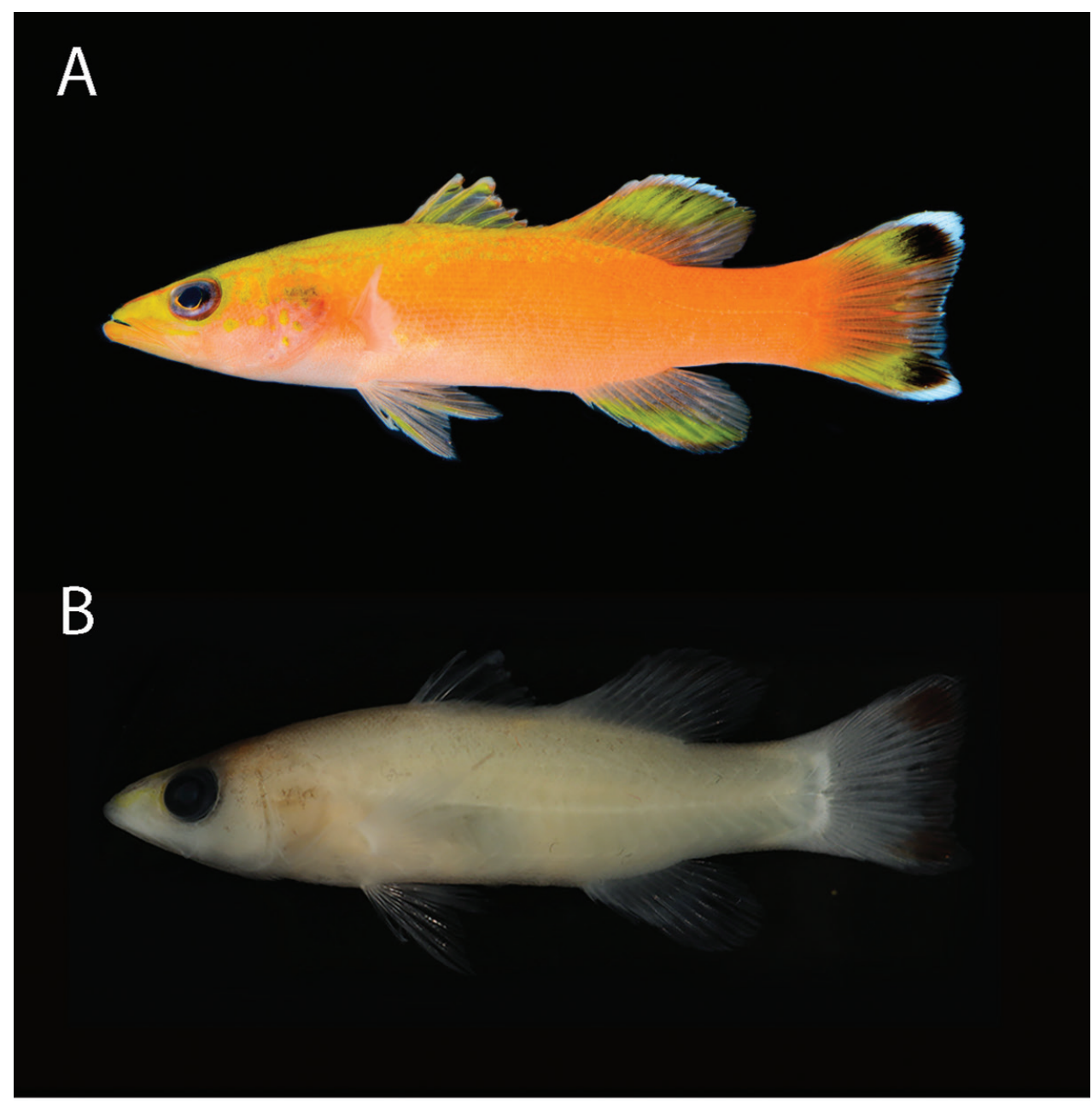

C

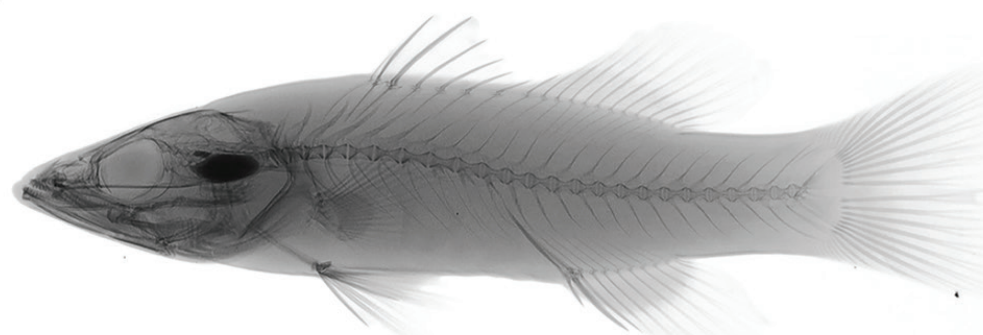

Figure I. Holotype of Liopropoma incandescens (CAS 246199), $54.15 \mathrm{~mm}$ SL, collected at a depth of $130 \mathrm{~m}$ off Ahnd (Ant) Atoll, Pohnpei, Federated States of Micronesia. Photographs by L. A. Rocha and J. Fong. 
maxillary length 12.7; least caudal-peduncle depth 14.6; caudal-peduncle length 13.5. Fin lengths: dorsal-fin spines: (I) 4.6; (II) 9.9; (III) 10.7; longest dorsal-fin soft ray the $10^{\text {th }}$, length 17.4; lengths of anal-fin spines: (I) 3.9; (II) 10.1; (III) 11.3; longest anal soft ray the $5^{\text {th }}$, length 18.1; caudal-fin length 23.2; pectoral-fin length 26 , fin short, not reaching vertical between anus and dorsal fin; pelvic-fin length 19, fin reaching vertical slightly posterior to base of $5^{\text {th }}$ dorsal-fin spine.

Interorbital region flat; mouth oblique, maxilla almost reaching vertical crossing posterior border of pupil; prominent bony projection on posteroventral corner of maxilla; lower jaw projected. Anterior nostril in thin, membranous tube, situated close to tip of snout; posterior nostril a simple opening, situated close to orbit. Lateral line strongly arched above pectoral fin, highest point below fourth dorsal-fin spine. Trunk covered with ctenoid scales, scales becoming weakly ctenoid anteriorly and cycloid on head. Head fully scaled except over branchiostegal area. Short membrane covered by scales anteriorly to first dorsal-fin spine, six rows of scales covering basal anterior portion of soft dorsal fin, decreasing uniformly to two scales at posterior basal portion of soft dorsal fin. Anal fin with two to five rows of scales basally (more rows between second and fourth spine. Caudal fin almost completely scaled, except for distal tips of rays. Scales present on pectoral-fin base, pelvic-fin base, and on proximal portion of pelvic fin. Jaw teeth small; upper and lower jaws with bands of villiform teeth, bands slightly wider anteriorly. Vomer oval patch of small teeth. Palatines with several rows of small teeth in long and narrow bands at each side of mouth. Opercle with one conspicuous middle spine. Margin of upper and lower limb of preopercle smooth.

Color in life. Alive and freshly euthanized holotype (Figures 1A, 2) with coloration as follows: snout, top of head and trunk yellow, grading to vivid orange on a diagonal around upper two-thirds of body to caudal fin. Pale pink checks with yellow blotches behind eye, on operculum, and on dorsal-most part of body from head to base of soft dorsal fin. Indistinct orange line from tip of snout, across top of eye, continuing to above preopercle edge. Pupil black with yellow outer margin; eye pale purple and orbit with orange ring along margin. Pale pink-orange to peach-colored throat, continuing below pectoral fins, and across belly. Dorsal fin with yellow-orange tipped spines and mostly translucent inter-spinous membranes; base of soft dorsal-fin rays (ventral third, scaled region) orange; soft dorsal fin central upper region yellow from first to eighth ray; margin of the first soft dorsal-fin ray orange, transitioning to white from second to eighth; dorsal portion between eighth and twelfth soft ray light orange, with no white margin and no yellow. Pectoral fin light orange, yellow anteriorly (first ray). Upper two-thirds of anal fin orange, distal region yellow from second to ninth ray; anal-fin margin white along second to ninth ray with a pale orange sub-border, translucent along tenth to twelfth ray. Central portion of caudal fin with orange rays and membranes, with white pigments in the distal posterior third; upper and lower portions of caudal fin yellow with orange base; two pronounced oval-shaped black spots with posterior white margins, approximately the same size as orbit, on outer upper and lower caudal lobes. 


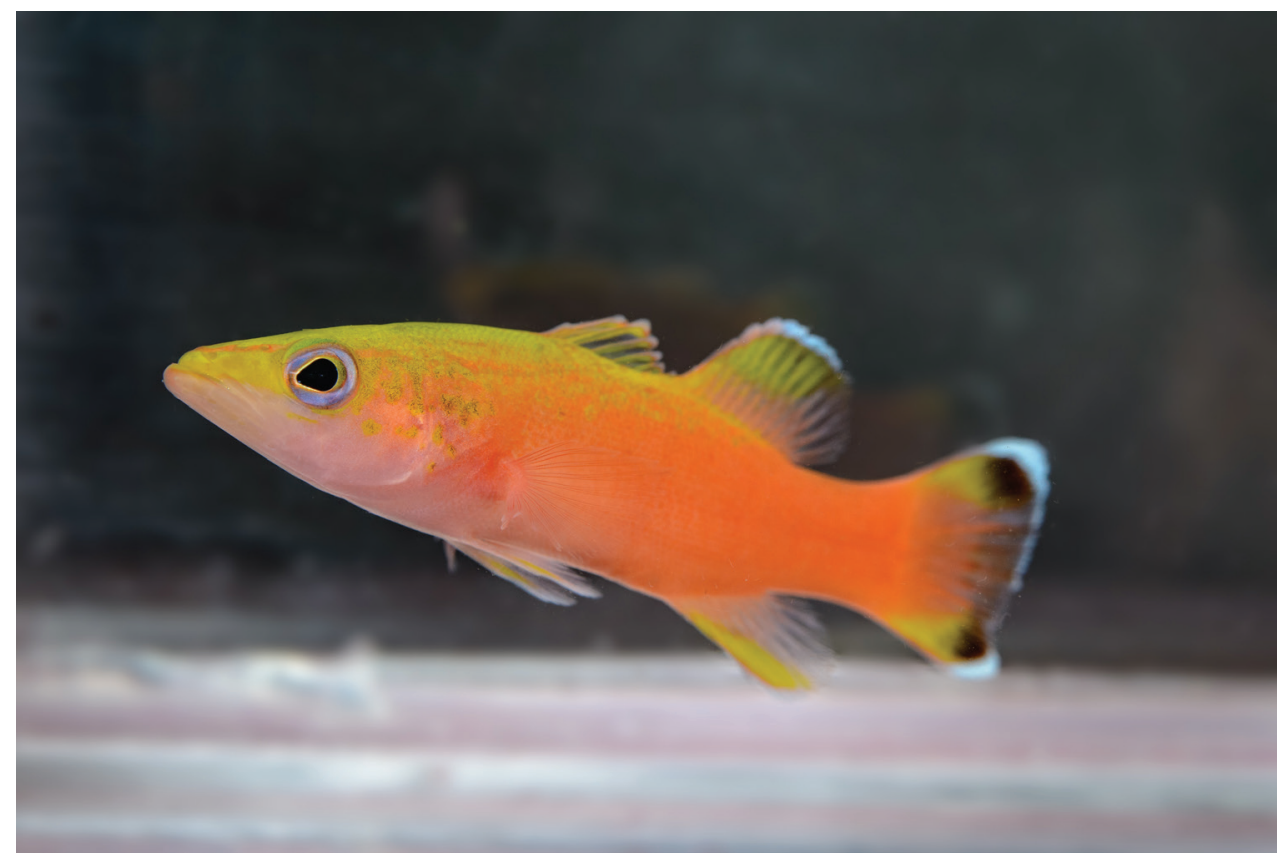

Figure 2. Holotype of Liopropoma incandescens (CAS 246199), $54.15 \mathrm{~mm}$ SL, shown alive in an aquarium. Photograph by L. A. Rocha.

Color in alcohol. In alcohol (Figure 1B), body light beige, pigment only present on a small patch of yellow on the snout, and the two pronounced dark spots on distal upper and lower caudal fin lobes.

Distribution. Liopropoma incandescens sp. nov. is known based on one specimen collected at a depth of $130 \mathrm{~m}$ in Ahnd (Ant) Atoll, Pohnpei, Federated States of Micronesia. The lack of records for the species in other MCEs of the Pacific Ocean is probably due to its cryptic habits combined with the lack of sampling at those depths across the wider region.

Habitat and behavior. Liopropoma incandescens sp. nov. has a cryptic habit and was discovered and collected in a small rocky crevice along a steep limestone coral reef drop-off at a depth of $130 \mathrm{~m}$ (Figure 3$)$. A second individual $(-10 \mathrm{~cm}$ length) was sighted in the same area, together with species such as Tosanoides annepatrice Pyle, Greene, Copus \& Randall, Centropyge abei Allen, Young \& Colin, Odontanthias sp. and Roa sp., but was not collected.

Etymology. The specific name is a noun in apposition from the Latin, incandescens, to glow. The vivid yellow to orange incandescent coloration of the species prompted us to select this name.

Comparisons. The color of Liopropoma incandescens sp. nov. sets it apart from all other species in the genus: the gradient from yellow to orange and the two black spots on the upper and lower caudal fin lobes are unique. The only other species with black spots on upper and lower caudal fin lobes is Liopropoma carmabi (Randall), from 


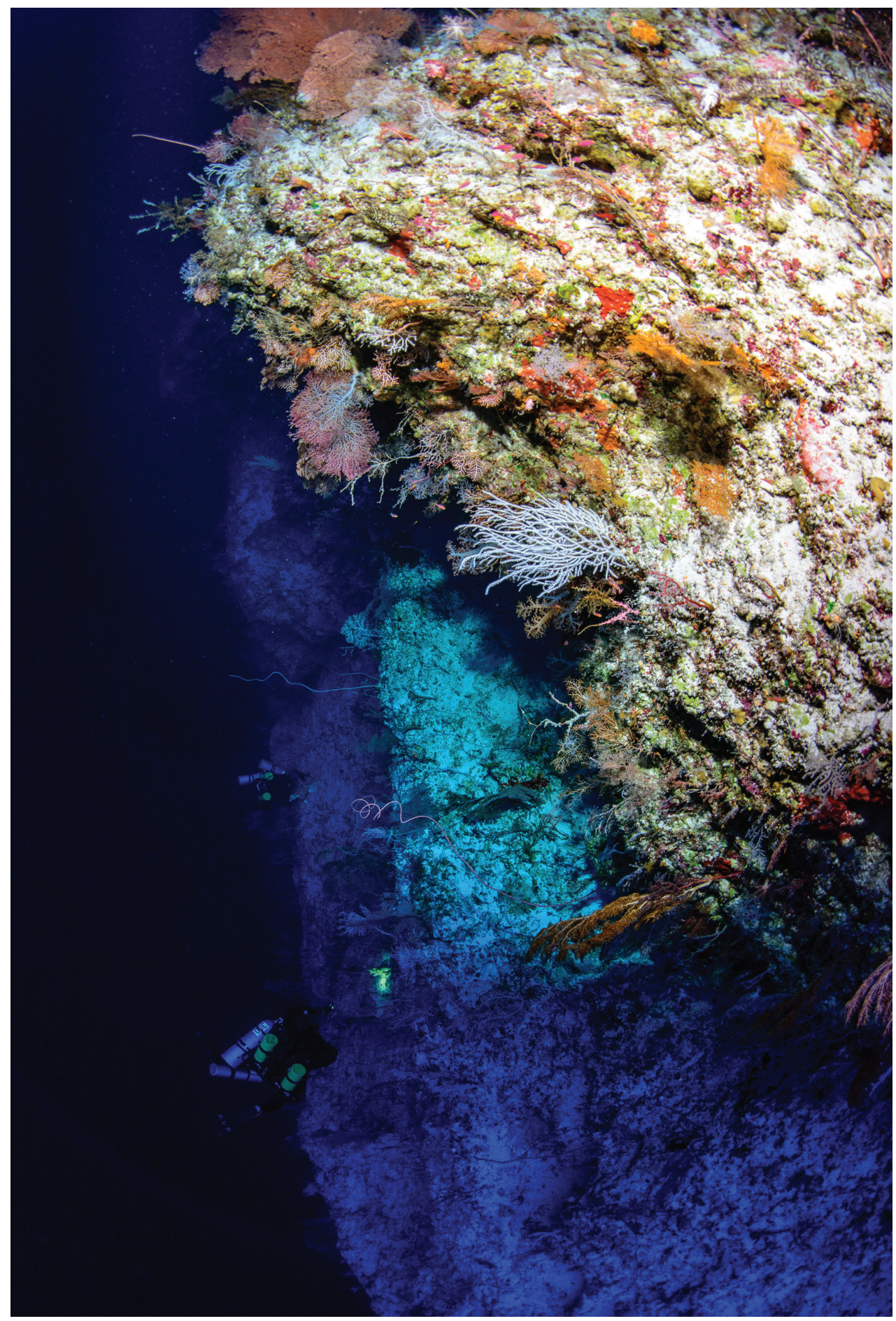

Figure 3. Coral reef wall at a depth of $130 \mathrm{~m}$, the habitat where Liopropoma incandescens was discovered in Ahnd (Ant) Atoll, Pohnpei. Photograph by L. A. Rocha. 
the Western Atlantic, which has alternating orange and pink horizontal lines running from the snout to the caudal fin. Moreover, most species of Liopropoma have between 44 and 54 lateral-line scales, whereas $L$. incandescens sp. nov. shares a high number of lateral-line scales (62) exclusively with Liopropoma maculatum (Döderlein) (Randall and Taylor 1988, Kon et al. 1999, Wirtz and Schliewen 2012, Baldwin and Johnson 2014, Baldwin and Robertson 2014). Liopropoma incandescens sp. nov. differs from $L$. maculatum by the lower number of pectoral fin-ray counts (14 vs 15-16), the presence of two black spots on outer upper and lower lobes of the caudal fin, a more slender body (body depth 4.6 vs 3.2-4 in SL), and shorter snout (4 vs 3.3-3.7 in HL).

\section{Discussion}

The shallow coral reefs of Micronesia are known to shelter a high diversity of reef fishes (Myers 1999, Kulbicki et al. 2013), and the clear waters of central Pacific seem also to favor biodiverse communities at mesophotic depths. However, communities change considerably along the shallow to mesophotic gradient. When studying shallow and deep reefs of Pohnpei, both Coleman et al. (2018) and Rocha et al. (2018) found shifts in species composition and abundance as depth increases, showing high abundances of serranid fishes at deeper depths. In general, Liopropoma are cryptic, and most species have their depth range spanning mesophotic depths (Randall and Taylor 1988, Baldwin and Robertson 2014). Therefore, continued exploratory work on mesophotic coral ecosystems is poised to reveal additional new species within this genus.

\section{Acknowledgements}

This work was funded by the generous support of donors to the California Academy of Sciences' Hope for Reefs Initiative. We would like to thank Mauritius V. Bell for diving support, Jon Fong for taking the radiographs and photo of the type specimen, and D. Catania for helping with access to the CAS collection. Logistical support in Pohnpei was provided by Walter Wilbur and family at the Nihco Marine Park, Allois Malfitani, and the Conservation Society of Pohnpei (CSP).

\section{References}

Arango BG, Pinheiro HT, Rocha C, Greene BD, Pyle RL, Copus JM, Shepherd B, Rocha LA (2019) Three new species of Chromis (Teleostei, Pomacentridae) from mesophotic coral ecosystems of the Philippines. ZooKeys 835: 1-15. https://doi.org/10.3897/zookeys. 835.27528 
Baldwin CC, Johnson GD (2014) Connectivity across the Caribbean Sea: DNA barcoding and morphology unite an enigmatic fish larva from the Florida straits with a new species of sea bass from deep reefs off Curaçao. PloS ONE 9: e97661. https://doi.org/10.1371/journal. pone.0097661

Baldwin CC, Robertson DR (2014) A new Liopropoma sea bass (Serranidae, Epinephelinae, Liopropomini) from deep reefs off Curaçao, southern Caribbean, with comments on depth distributions of western Atlantic liopropomins. ZooKeys 92: 71-92. https://doi. org/10.3897/zookeys.409.7249

Coleman RR, Copus JM, Coffey DM, Whitton RK, Bowen BW (2018) Shifting reef fish assemblages along a depth gradient in Pohnpei, Micronesia. PeerJ 6: e4650. https://doi. org/10.7717/peerj.4650

Copus J, Ka'apu-Lyons C, Pyle R (2015) Luzonichthys seaver, a new species of Anthiinae (Perciformes, Serranidae) from Pohnpei, Micronesia. Biodiversity Data Journal 3: e4902. https://doi.org/10.3897/BDJ.3.e4902

Eschmeyer W, Fong J (2018) Species by Family/Subfamily in the Catalog of Fishes. http:// researcharchive.calacademy.org/research/ichthyology/catalog/SpeciesByFamily.asp

Kon T, Yoshino T, Sakurai Y (1999) Liopropoma dorsoluteum sp. nov., a new serranid fish from Okinawa, Japan. Ichthyological Research 46: 67-71. https://doi.org/10.1007/BF02674949

Kulbicki M, Parravicini V, Bellwood DR, Arias-Gonzàlez E, Chabanet P, Floeter SR, Friedlander A, McPherson J, Myers RE, Vigliola L, Mouillot D (2013) Global Biogeography of Reef Fishes: A Hierarchical Quantitative Delineation of Regions Stergiou KI (Ed.). PLoS ONE 8: e81847. https://doi.org/10.1371/journal.pone.0081847

Myers RF (1999) Micronesian Reef Fishes: A Comprehensive Guide to the Coral Reef Fishes of Micronesia. Coral Graphics, Barrigada, 330 pp.

Pinheiro HT, Goodbody-Gringley G, Jessup ME, Shepherd B, Chequer AD, Rocha LA (2016) Upper and lower mesophotic coral reef fish communities evaluated by underwater visual censuses in two Caribbean locations. Coral Reefs 35: 139-151. https://doi.org/10.1007/ s00338-015-1381-0

Pinheiro HT, Rocha C, Rocha LA (2018) Tosanoides aphrodite, a new species from mesophotic coral ecosystems of St. Paul's Rocks, Mid Atlantic Ridge (Perciformes, Serranidae, Anthiadinae). ZooKeys 786: 105-115. https://doi.org/10.3897/zookeys.786.27382

Pyle RL, Greene BD, Copus JM, Randall JE (2018) Tosanoides annepatrice, a new basslet from deep coral reefs in Micronesia (Perciformes, Percoidei, Serranidae). ZooKeys 786: 139153. https://doi.org/10.3897/zookeys.641.11500

Randall JE, Taylor L (1988) Review of the Indo-Pacific fishes of the serranid genus Liopropoma, with descriptions of seven new species. Indo-Pacific Fishes 16: 1-47.

Rocha LA, Pinheiro HT, Shepherd B, Papastamatiou YP, Luiz OJ, Pyle RL, Bongaerts P (2018) Mesophotic coral ecosystems are threatened and ecologically distinct from shallow water reefs. Science 361: 281-284. https://doi.org/10.1126/science.aaq1614

Rocha LA, Pinheiro HT, Wandell M, Rocha CR, Shepherd B (2017) Roa rumsfeldi, a new butterflyfish (Teleostei, Chaetodontidae) from mesophotic coral ecosystems of the Philippines. ZooKeys 709: 127-134. https://doi.org/10.3897/zookeys.709.20404 
Shepherd B, Phelps T, Pinheiro HT, Pérez-Matus A, Rocha LA (2018a) Plectranthias abiahiata, a new species of perchlet from a mesophotic ecosystem at Rapa Nui (Easter Island) (Teleostei, Serranidae, Anthiadinae). ZooKeys 762: 105-116. https://doi.org/10.3897/zookeys.762.24618

Shepherd B, Wandell M, Pinheiro HT, Rocha LA (2018b) SubCAS: A Portable, Submersible Hyperbaric Chamber to Collect Living Mesophotic Fishes. Frontiers in Marine Science 5: 187. https://doi.org/10.3389/fmars.2018.00187

Wirtz P, Schliewen UK (2012) A new species of Liopropoma Gill, 1862 from the Cape Verde Islands, Eastern Atlantic. Spixiana 35: 149-154. 